\title{
Diplodomica II. Repugnatorial Secretion of Ecuadorian Endemic Millipede Rhinocricus sp. (Diplopoda, Spirobolida, Rhinocricidae) from Orellana Province, Amazonia, Ecuador ${ }^{\dagger}$
}

\author{
Juan Enrique Tacoronte Morales ${ }^{1, *}$ and Maria Teresa Cabrera ${ }^{2}$
}

Citation: Morales, J.E.T.; Cabrera, M.T. Diplodomica II. Repugnatorial Secretion of Ecuadorian Endemic Millipede Rhinocricus sp.

(Diplopoda, Spirobolida, Rhinocricidae) from Orellana Province, Amazonia, Ecuador. Chem. Proc. 2021, 3 , 90. https://doi.org/10.3390/10.3390/ ecsoc-24-08435

Academic Editors: Julio A. Seijas and M. Pilar Vázquez-Tato

Published: 14 November 2020

Publisher's Note: MDPI stays neutral with regard to jurisdictional claims in published maps and institutional affiliations.

Copyright: (c) 2020 by the authors. Submitted for possible open access publication under the terms and conditions of the Creative Commons Attribution (CC BY) license (http://creativecommons.org/licenses/by/4.0/).
1 Chemical Engineering Division, Faculty of Science \& Engineering, Technical University of Esmeraldas, Campus "Nuevos Horizontes", PC 080150 Esmeraldas, Ecuador

2 Faculty of Health Sciences, Universidad de Las Américas, UDLA, UDLA-Park, PC 170124 Quito, Ecuador; maria.cabrera@udla.edu.ec

* Correspondence: juan.tacaronte.morales@utelvt.edu.ec

+ Presented at the 24th International Electronic Conference on Synthetic Organic Chemistry, 15 November-15 December 2020; Available online: https://ecsoc-24.sciforum.net/.

\begin{abstract}
Millipedes (Myriapoda: Diplopoda) represents one of the oldest and most evolutionary successful classes of invertebrates. The order Spirobolida is dominantly tropical, and the family Rhinocricidae is widely distributed in the Ecuadorian edaphic fauna inhabiting the Amazonia region. The millipedes collected were stimulated mechanically, and an ejected repugnatorial fluid was subjected to structural analysis. The analysis of the defensive-repugnatorial secretion of the endemic millipede Rhinocricus sp., inhabiting in the Amazonian region of Orellana, Republic of Ecuador, and chemical evidence (chromogenic reactions: KI starch paper and rodanine test in aqueous ammonia) as well, revealed the quinonoide composition of the secretion. We identified 2-methyl-3-methoxy1,4-benzoquinone as an active major component.
\end{abstract}

Keywords: millipede; Rhinocricus; Ecuador; defensive secretion; quinonoids; benzoquinones

\section{Introduction}

Comprising probably about 80,000 species, of which only $10 \%$ have been described, millipedes (Myriapoda: Diplopoda) represent one of the oldest, largest, and evolutivelly successful classes of the Animal Kingdom and invertebrates [1,2]. The group contains forest floor-dwellers, stratobions, few cavernicoles, edaphobionts, and epiphytobionts [3]. Within their biotopes, millipedes function ecologically as detritivores and play major roles in the reduction of plant litter and formation of organic soil. The order Spirobolida is dominantly tropical in its distribution and diversification and the family Rhinocricidae is widely distributed in the Ecuadorian edaphic fauna inhabiting in the Amazonia region [4]. The defensive allomones substances and volatile mixtures of about 80 species of millipedes have been analyzed, and about 40 substances of different chemical nature as, e.g., hydrocyanic acid, esters, acids, aromatic and aliphatic aldehydes, substituted phenols and their derivatives, polysubstituted 1,4-benzoquinones, and benzoquinoids in general, quinazolines, spiro-pyrrolizidines and their oximes, aromatic nitriles, and even an alicyclic amino-nitro compound and monoterpenes have been isolated and identified [5-10]. The most frequently detected are 1,4-benzoquinones, substituted, generally, by one or two methyl, ethyl or methoxyl groups, and/or even their combination, and they have been found in several millipede orders, more often in those belonging to Juliformia. [5,11-13].

The repugnatorial glands, from which defensive noxious policomponent organic mixtures are ejected, are located, dorso-laterally, approximately at the dorsum on most 
diplosegments (except for the first five anterior and the last three posterior ones). Anatomically, Rhinocricus sp., has glands similar to those found in many species of the orders Spirobolida, Spirostreptida, Julida, and Callipodia.

There are no reports detailing chemical ecology, biological activity and structuralcompositional aspects of defensive secretions of Millipedes inhabiting in the Amazonian region of Orellana, Republic of Ecuador. The reported results constitute the first chemical analysis of repugnatorial ejections isolated and collected from individuals of Orellana endemic millipede gen. Rhinocricus sp. (Figure 1).

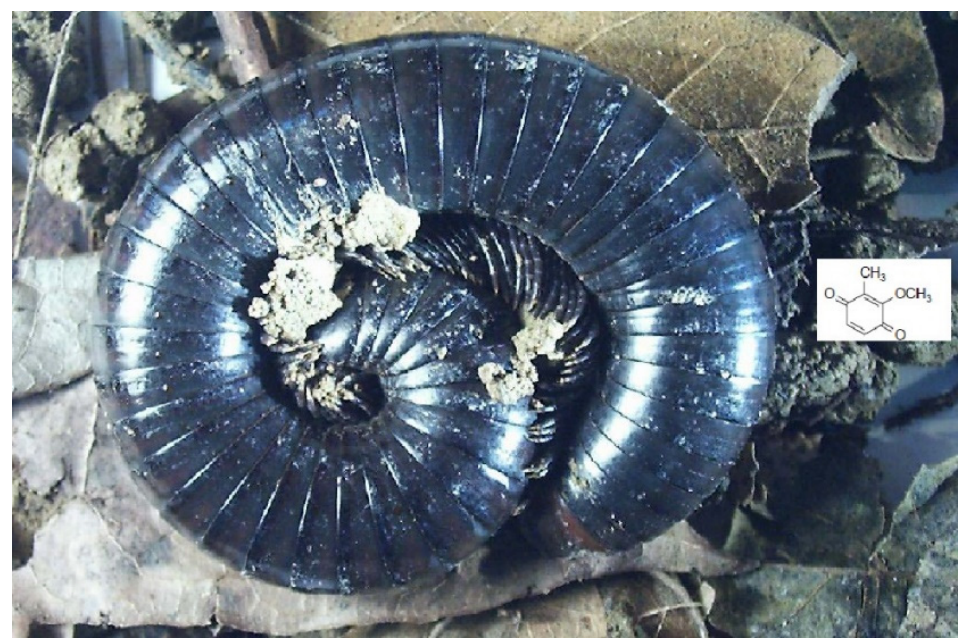

Figure 1. Rhinocricus sp. (Spirobolida, Rhinocricidae) from Palmar del Rio, Orellana, Ecuador.

\section{Materials and Methods}

All reagents used were supplied by MERCK, Darmstadt, Germany, and were used without prior purification.

\subsection{IR Spectroscopy}

The infrared spectra were recorded on a PHILIPS ANALYTICAL FTIR PU-9600 spectrophotometer, Germany; the samples were prepared in potassium bromide $(\mathrm{KBr})$ tablets at $25^{\circ} \mathrm{C}$. Alternatively, the spectra were recorded in a JASCO-Canvas 4600, Japan system in $\mathrm{CsBr}$ tablets at $25^{\circ} \mathrm{C}$.

\subsection{NMR Spectroscopy}

NMR spectra were recorded on a BRUKER AC-250 instrument, Germany, at $25^{\circ} \mathrm{C}$. The protonic chemical $(\delta)$ shifts are given in ppm, using tetramethylsilane as internal reference (TMS, $\delta=0.0$ ) and as a solvent $\mathrm{CDCl}_{3}$. The chemical shifts $(\delta)$ for $13 \mathrm{C}$ refer to the central peak of the $\mathrm{CDCl}_{3}$ solvent at $77.03 \mathrm{ppm}$.

\subsection{Gas Chromatography Coupled to Mass Spectrometry (GC-MS)}

A Hewlett-Packard 6890 gas chromatograph (Palo Alto, CA, USA) with 5973 quadrupole detection system (GC-MS) was used. The separations were carried out through a capillary column of Ultra 2 type (J \& W Scientific, Folsom, CA, USA), $12 \mathrm{~m}$ long and 0.22 $\mathrm{mm}$ of internal diameter. As carrier gas, He was used at a flow of $1 \mathrm{~mL} / \mathrm{min}$. Temperature ramp: $60{ }^{\circ} \mathrm{C}$ with increments of $10^{\circ} \mathrm{C} / \mathrm{min}$ up to $300{ }^{\circ} \mathrm{C}$ (isothermal $5 \mathrm{~min}$.). Run time 30 min. Injection volume $2 \mu \mathrm{L}$ at a temperature of $280^{\circ} \mathrm{C}$, in split mode (1:10 ratio). The ionization source was IE at $70 \mathrm{eV}$ operating at $230^{\circ} \mathrm{C}$. Acquisition mode: Full Scan. Range of $\mathrm{m} / \mathrm{e} 40-700$.

The following databases were used for structural characterization: Nist98 (National Institute of Standards and Technology, Gaithersburg, MD, USA), PMW_TOX2 (Wiley Library and Pfleger Maurer Weber (PMW), National Metrology Institute of Japan (NMIJ, 
Tokyo, Japan), and National Institute of Advanced Industrial Science and Technology (AIST, Tokyo, Japan). In addition, the databases that report the chemical composition of the invertebrate defensive secretions (https://www.pherobase.com, accessed 16 October 2020) and their GC-MS (libraries for the rapid identification of metabolites in complex biological samples, Max-Planck Institute of Plant Molecular Physiology, Postdam, Germany) were considered. Using the reported sources and m/e data from the GC-MS, the most likely structures and their fragmentation mechanisms are postulated. Identification of the components was based on comparison of GC retention data and mass spectra. Each component was quantified using n-hexadecane as internal standard.

\subsection{Biological Material}

The millipede studied, Rhinocricus sp., (Rhinocricidae, Spirobolida), is one of the largest endemic species of this genus inhabiting in the Ecuadorian edaphic fauna of Amazonian macroinvertebrates and representing a largest group in biomass. Adult specimens reach over 150-170 $\mathrm{mm}$ with a diameter of about $10-16 \mathrm{~mm}$ and weight of $25-28 \mathrm{~g}$. Adult individuals (males) of the millipede species gen. Rhinocricus sp. were collected, gently, by hand picking, in Palmar del Rio, Francisco de Orellana Province $\left(0^{\circ} 19^{\prime} \mathrm{S}\right.$ latitude and $77^{\circ} 04^{\prime} \mathrm{W}$ longitude, at altitude of $280 \mathrm{~m}$ ) during the months of May-July 2019, from raked forest soil at the edge of the pluvial tropical evergreen forest, consisting mostly of Heliconia sp., Cecropia sp., Clusia sp., and Ficus sp., $175 \mathrm{Km}$ East from Quito City, and maintained in laboratory conditions for 20 days by feeding on litter at $25^{\circ} \mathrm{C}$ under $16 \mathrm{~L}: 8 \mathrm{D}$ photoperiod and reared in plastic boxes (terrariums $30 \times 15 \times 15 \mathrm{~cm}$ ), which were kept humid by spraying with water every other day. Voucher specimen RA-002 was conserved in the Laboratory of Ecology at Centre of Biology, Central University of Ecuador (Prof. Franklin Gavilánez), and several individuals (5) were kept in the Organic Chemistry Laboratory of the Faculty of Science \& Technology at Technical University of Esmeraldas, Ecuador (voucher 004-007).

Millipedes gen. Rhinocricus respond to disturbance by coiling up, and they produce, after mechanical irritation or predator disturbance, a considerable quantity of defensive noxious secretion that could be ejected to a distance of $20-25 \mathrm{~cm}$.

After mechanical stimulation with a pincette, $850 \mu \mathrm{g}$ of a deep brown-red secretion with intense phenolic odor was released from lateral ozopores and obtained by means of glass capillary from the individual studied. The secretion $(650-800 \mu \mathrm{g} /$ individual) is absorbed on Whatman 40 filter paper and cooled to $-10^{\circ} \mathrm{C}$. The filter paper is extracted with diethyl ether $(5 \times 2 \mathrm{~mL})$, and the ether extracts are concentrated with $\mathrm{N}_{2}$ flow $(\mathrm{g})$ to dryness, stored at $-10^{\circ} \mathrm{C}$ in $1 \mathrm{~mL}$ Eppendorf vials, and sealed with parafilm for further analysis. To each vial, with the dry extract, dichloromethane $(1 \mathrm{~mL})$ is added, the mixture is stirred, filtered through $0.45 \mu \mathrm{m}$ frit, and injected into the GC-MS $(2-20 \mu \mathrm{L})$. The ability of the secretion to react strongly with KI starch paper suggested the presence of quinones. This was corroborated by spot analysis using a positive test for a p-quinone with rhodamine and aqueous ammonia (Figure 2). 


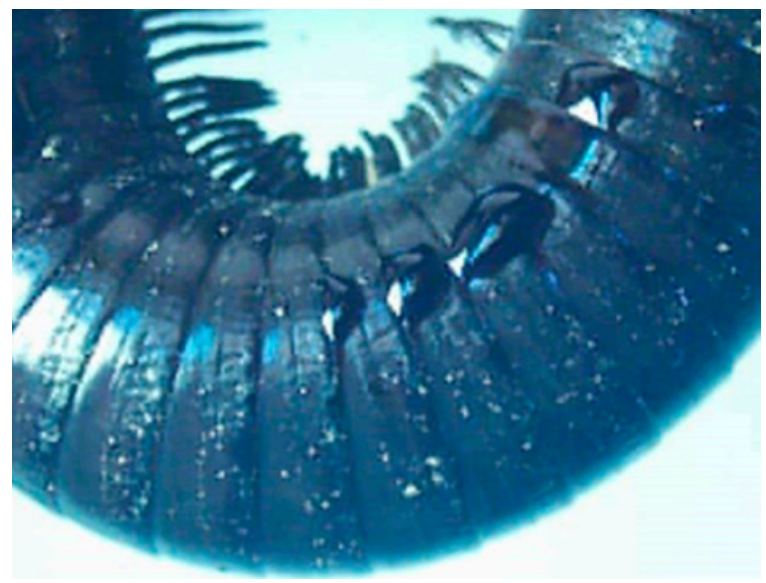

Figure 2. Droplets of defensive repugnatorial secretion ejected from ozopores after mechanical stimulation with a pincette and prior its collecting by means of glass capillary.

\section{Results and Discussion}

The molecular and basic peaks of the mass spectrum is formed by the ions of a substance $\mathrm{m} / \mathrm{z} \mathrm{M}^{+} 152$ (corresponding to $\mathrm{C}_{8} \mathrm{H}_{8} \mathrm{O}_{3}{ }^{+}$) from which the fragmentation pattern shows two paths: the first one is an elimination of the neutral molecule $\mathrm{CH}_{2} \mathrm{O}$ (from methoxyl), generating the most intensive peak of the spectrum of $\mathrm{m} / \mathrm{z} 122\left(\mathrm{C}_{7} \mathrm{H}_{6} \mathrm{O}_{2}{ }^{+}\right.$ Rel.int.73\%) and then successively two CO molecules peaks m/z 94, $\left(\mathrm{C}_{6} \mathrm{H}_{6} \mathrm{O}^{+}\right)$and $\mathrm{m} / \mathrm{z} 66$ $\left(\mathrm{C}_{5} \mathbf{H}_{6}{ }^{+}\right)$. In the second path, first, $\mathrm{C}_{2} \mathrm{H}_{3} \mathrm{O}$ will be eliminated whereby ions $\mathrm{m} / \mathrm{z} 109$ $\left(\mathrm{C}_{5} \mathrm{H}_{3} \mathrm{O}_{2}{ }^{+}\right)$arise, and then, again, we observe the elimination of two neutral molecules $\mathrm{CO}$ i.e., $\mathrm{m} / \mathrm{z} 81\left(\mathrm{C}_{5} \mathrm{H}_{3} \mathrm{O}^{+}\right)$and $\mathrm{m} / \mathrm{z}$ 51. In addition to the described fragmentations, the elimination of methyl and water from molecular ion occurs in parallel, the last ion $\left(\mathbf{M}-\mathbf{H}_{2} \mathbf{O}\right)^{+}$ forming the peak of a relative intensity of only $2 \%$. It can be judged from the described fragmentation patterns (and from the composition of the individual ions) that the analyzed compound is a typical substituted benzoquinone by one $\mathrm{CH} 3$ - group and one OCH3- group.

The NMR spectra $\left(\mathrm{CDCl}_{3}{ }^{1} \mathrm{H}-250 \mathrm{MHz}\right.$ and $\left.{ }^{13} \mathrm{C}-100 \mathrm{MHz}\right)$ shown: for ${ }^{1} \mathrm{H} \mathrm{NMR}, \boldsymbol{\delta}$, ppm: 6.72-6.67 [d, $1 \mathrm{H}], 6.62-6.57[\mathrm{~d}, 1 \mathrm{H}], 4.03$ [s, 3H], $1.95[\mathrm{~s}, 3 \mathrm{H}]$; for ${ }^{13} \mathrm{C} \mathrm{NMR}, \boldsymbol{\delta}, \mathrm{ppm}$ : 188, 34 (C-1); 129, 40 (C-2); 156, 15 (C-3); 175,52 (C-4); 136,45 (C-5); 137.85 (C-6); 11.22 (C-7); 59.48 (C-8).

The FTIR (Fourier Transform Infrared Spectroscopy) spectrum shows the valence vibrations of the $\mathrm{C}=\mathrm{O}$ bond at 1645 and $1662 \mathrm{~cm}^{-1} ; \mathrm{C}=\mathrm{C}$ at $1590 \mathrm{~cm}^{-1} ; \mathrm{C}-\mathrm{H}\left(-\mathrm{OCH}_{3}\right)$ at $2840 \mathrm{~cm}^{-1} ;(-\mathrm{CH} 3)$ at $2940 \mathrm{~cm}^{-1}$. When comparing the spectrum of three isomers of methylmethoxy-1,4-benzoquinones from the collection of spectra, it was explicitly proved that the substance, isolated as a major component, is 2-methyl-3-methoxy-1,4- benzoquinone (Figure 3).

The biological effects of this substance were evaluated experimentally, together with several further substances isolated from the defensive secretions of the millipedes, on forest ants as chief enemies of the millipedes in natural conditions $[5,14]$ and some pathogenic fungus and bacteria [15]. The results of the preliminary experiments showed a quick repellent effect vs. ants gen. Paraponera and Atta and a microbicide action vs. Pseudomonas and Staphylococcus $[16,17]$. The secretions also irritate the more sensitive parts of epidermis, vertebrate skin and human mucoses, and especially the cornea of the eyes. 


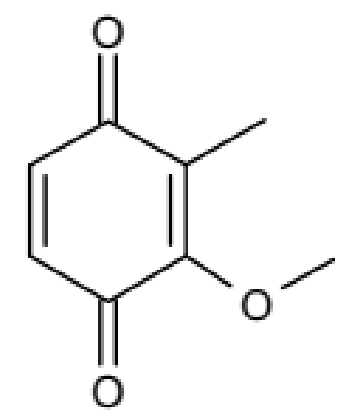

Figure 3. Major component, isolated from defensive repugnatrial secretion of Rhinocricus sp. inhabiting in Orellana, an Amazonian region from Ecuador: 2-methyl-3-methoxy-1,4- benzoquinone.

2-methyl-3-methoxy-1,4-benzoquinone is the most prevalent active substance in the defensive secretions of millipedes, and it has been found in about 30 species of the subclass Helminthomrpha. It is not present in only the orders Callipodia, Polyzoniida, and Polydesmida, as they have a different type of gland. Its occurrence in the orders Spirobolida, Spirostreptida, and Julida appears very often.

\section{Conclusions}

The analysis (FTIR-NMR-GC/MS) of the defensive-repugnatorial secretion of the endemic millipede Rhinocricus sp., inhabiting in the Amazonian region of Orellana, Republic of Ecuador, and chemical evidence (chromogenic reactions: KI starch paper and rodanine test in aqueous ammonia) as well, revealed the quinonoide composition of the secretion. We identified 2-methyl-3-methoxy-1,4-benzoquinone as an active major component. This is the first report related to analysis of chemical composition of repugnatorial secretion of Ecuadorian Rhinocricidae from the Amazonian region. The results concerning biological action (repellent and microbiocidal effects) will be reported soon.

Author Contributions: Individual contributions are as follows: J.E.T.M. conceptualization and methodology, funding acquisition investigation and spectral data analysis; M.T.C. writing and preparation, review and editing. All authors have read and agreed to the published version of the manuscript.

Funding: This research received no government, academic or external funding.

Acknowledgments: This study was supported, in part, by the institutional support from Prometheus Project Ecuador "Chemical Bioprospecting of Tropical Biodiversity" 2016-2017.

Conflicts of Interest: The authors declare no conflict of interest.

\section{References}

1. Hoffman, R. Classification of the Diplopoda. Mus. d'Hist. Nat. Geneve 1979, 1-237.

2. Sierwald, P.; Bond, J. Current status of the myriapod Class Diplopoda (millipedes): Taxonomic diversity and phylogeny. Annu. Rev. Entomol. 2007, 52, 401-420.

3. Bueno-Villegas, J.; Petra Sierwald, P.; Bond, J. Diplopoda. In Biodiversidad, Taxonomía y Biogeografía de Artrópodos de Mexico; Universidad Nacional Autónoma de México, Instituto de Biología: Mexico City, Mexico, 2004; Chapter 22, pp. 569-578.

4. Hoffman, R.; Golovatch, S.; Adis, J.; de Morais, J. Practical keys to the orders and families of millipedes of the Neotropical region (Myriapoda: Diplopoda). Amazoniana 1996, 14, 1-35.

5. Eisner, T.; Alsop, D.; Hicks, K.; Meinwald, J. Defensive secretions of millipedes. In Handbook of Experimental Pharmacology; Sergio, B., Ed.; Arthropod Venoms; Springer: Berlin/Heidelberg, Germany, 1978; Volume 48, pp. 41-72.

6. Arab, A.; Zacarin, G.; Fontanetti, C.; Camargo-Mathias, M.; Dos-Santos, M.; Cabrera, A. Composition of the defensive secretion of the neotropical millipede Rhinocricus padbergi Verhoeff 1938 (Diplopoda: Spirobolida: Rhinocricidae). Entomotropica 2003, 18, $79-82$. 
7. Deml, R.; Huth, A. Benzoquinones and hydroquinones in defensive secretions of tropical millipedes. Naturwissenschaften 2000, 87, 80-82.

8. Rukhsana, K.; Vijesh, V.; Akhilesh, V.; Jisha, K.; Priya, B.; Bindu, P.U.; Sebastian, C. GC-MS Determination of chemical components in the bioactive secretion of Anoplodesmus saussurii (Humbert, 1865). Int. J. Pharm. Sci. Res. 2015, 6, 650-653.

9. Blum, M. Chemical Defenses of Arthropods; Academic Press: New York, NY, USA; London, UK, 1981; Volume 1-12, pp. 1-562.

10. Shear, W.A. The chemical defenses of millipedes (diplopoda): Biochemistry, physiology and ecology. Biochem. Syst. Ecol. 2015, 61, 78-117.

11. Eisner, T.; Hurst, J.; Keeton, W.; Meinwald, Y. Defense mechanisms of arthropods. XVI. Para-benzoquinones in the secretion of spirostreptoid millipedes. Ann. Entomol. Soc. Am. 1965, 58, 247-248.

12. Attygale, A.; Xu, S.C.; Meinwald, J. Defensive secretion of the millipede Floridobolus penneri. J. Nat. Prod. 1993, 56, 1700-1706.

13. Sekulic, T., Vujisic, Lj, Curcic, B., Mandic, B., Antic, D., Trifunovic, S., Godovac, D., Vajs, V., Tomic, V., Makarov, S. Quinones and non-quinones from the defensive secretion of Unciger transsilvanicus (Verhoeff, 1899) (Diplopoda, Julida, Julidae), from Serbia. Arch. Biol. Sci. Belgrade 2014, 66, 385-390.

14. Gibbs, D. Benzoquinone and Hydroquinone Derivatives for Use as Insect Feeding Deterrents. U.S. Patent 5780515, 14 July 1998.

15. Pesewu, G.; Billah, M.; Kwang, D.; Adofo, C.; Olutaiwo, M. Antibacterial activities of millipede extracts against selected bacterial pathogens. J. Microbiol. Antimicrob. Agents 2015, 1, 30-35.

16. Lana, E.; Carazza, F.; Takahashi, J. Antibacterial Evaluation of 1,4-Benzoquinone derivatives. J. Agric. Food Chem. 2006, 54, 20532056.

17. Monks, T.; Hanslij, R.; Cohen, G.; Ross, D.; Graham, D. Quinone Chemistry and Toxicity. Toxicol. Appl. Pharmacol. 1992, 112, 216. 